We went on to The Great Lake, and in many places I spotted nests of Black Magpies or Hill Bell Magpies-Jays (Strepera arguta) built in the fine cider gums (Eucalyptus gunnii, Hooker).

On the way to Bothwell there is a nest on a limb spanning the main road.

Before concluding I might mention that the one Jay (Strepera arguta) which frequents The Steppes homestead brought a mate this season, and when I was there I saw them with their family.

\title{
New Sub-species of Tit-Warblers (Acanthizae)
}

By A. G. CAMPBELL, J.P., R.A.O.U., Croydon, Victoria.

While examining a long series of Acanthiza to determine the limits of certain species, I discovered that important geographical regions are unrepresented although distinct sub-species occur therein. The following* offer good grounds for separation:-

Acanthiza pusilla leeuwinensis. Sub. sp. nov.

Upper surface dark brownish olive, tinged on rump with medal bronze (dark orange citrine); frontal patch less marked than in A.p.pusilla, but tawny to the base of feathers; forehead crescents ochraceous tawny with dark spots beneath and dusky fringes, like those of $A$. p. macularia; upper tail coverts and base of tail cinnamon brown; throat white with black striations heavier than in A.p.pusilla; flanks tawny olive; under tail coverts cinnamon buff; tail with black subterminal bar .3 inch wide, tips edged white on inner web; central feathers with an obscure dark spot (rudimentary bar) near tip; bill and legs brown; basal half of lower mandible light; eyes red. Length, 3.8 in.; bill, .35 in.; wing, 1.9 in.; tail, 1.7 in.; tarsus, .8 in.

Type male (103) from the collection of the late A. W. Milligan, and now in the Royal Australasian Ornithologists' Union's Collection, Melbourne. Taken 26/4/1911 at Wilson's Inlet, South West Australia, by F. Lawson Whitlock, R.A.O.U., collector.

Co-type female (253) in "H. L. White Collection,", National Museum, Melbourne. Similar to male, but tail tips more broadly marked with white on four outer feathers; under tail coverts darker ochraceous tawny; axillaries warm buff. Taken at Augusta, S.W. Australia, 6/4/1919, by T. Carter, R.A.O.U., collector.

I have seen similar skins from Irwin's Inlet, S.W. Australia. This is an interesting link between the Acanthiza of eastern and western Australia, and cannot be confused with Acanthiza apicalis.

* As Acanthiza (Motacilla) pusilla does not appear to have a definite type locality assigned to it, I hereby declare Port Jackson, New South Wales, to be the type locality ( see White, "Journal of Voyage to New South Wales," p. 257, 1790).

The same thing applies to Acanthiza nana, and I also declare Port Jackson, New South Wales, the type locality (see Vigors and Horsfield, “Trans. Linnæan Society, London,” vol. xv., p. 226, 1827).

In another article I propose to deal with the natural causes which apparently affect the distribution of the Acanthiza.-A.G.C. 
Acanthiza pusilla cambrensis. Sub sp. nov.

Upper surface brownish olive tinged on back and rump with medal bronze; forehead crescents tawny with dark spots beneath and dusky fringes like those of $A$. p. macularia; upper tail coverts brussels brown, the colour running well down the tail particularly on the outer webs; throat heavily striated with black, flanks buffy olive, becoming tawny on the lower portion; under tail coverts warm buff; abdomen and axillaries straw colour. Tail with subterminal black bar, .3 inch wide, no white edging to tips, central feathers with a small dark spot; bill and legs dark brown, base of lower mandible lighter; eyes red. Length, 3.9 in.; bill, .35 in.; wing, 2.1 in.; tail, 1.7 in.; tarsus, .8 in.

Type male (13) in collection of Edwin Ashby, Esq., R.A.O.U., Adelaide, taken at Cape Jervis, South Australia, 6/4/1917. Another skin (no sex) in the same collection, from Lucindale, S.A., is somewhat lighter in plumage, and has striations on throat and breast smaller and greyer.

Acanthiza pusilla dawsonensis. Sub. sp. nov.

Upper surface light olive, becoming dark citrine on back and rump; frontal and forehead feathers clay coloured to the base with faint dusky fringes only; upper tail coverts dresden brown; under surface mostly white; striations confined to throat, small, faint and grey; flanks buffy citrine; under tail coverts and axillaries white. Tail with black subterminal bar .3 inch wide, with distinct white edges to inner webs; central feathers with a dark spot near tip; bill and legs black; eyes light brown. Length 3.9 in.; bill, .32 in.; wing, 2.0 in.; tail, 1.8 in.; tarsus, .7 in.

Type male (224) in the "H. L. White Coll.," Nat. Mus., Melbourne, taken at Rio Station, Dawson River, Queensland, 13/10/1918, by H. G. Barnard, R.A.O.U.

Acanthiza nana belltrees. Sub. sp. nov.

Upper surface brightest dark citrine with yellowish tinge toward rump; very small light frontal spot on forehead; dark subterminal bar on tail; ear coverts fuscous with fine white shaft streaks; throat cinnamon buff with fine white shaft streaks; breast and abdomen bright strontian yellow; primaries yellow on outer webs at base; sides of breast, flanks yellowish citrine; eyes yellowish white; bill brown; legs black. Length, 3.6 in.; bill, .3 in.; wing, 1.9 in.; tail, 1.5 in.; tarsus, .7 in.

Type male (150) in "H. L. White Coll." Nat. Mus., Melbourne, taken at Scone, N.S.W., 20/6/1917, by S. W. Jackson, R.A.O.U. Cotype female (151) also in "H. L. White Coll.", Nat. Mus., Melbourne, taken at "Belltrees," Scone, N.S.W., 20/6/1917, is similar.

Acanthiza apicalis erema. Sub. sp. nov.

Upper surface drab, becoming buffy brown on rump; forehead crescents very indistinct; upper tail coverts cinnamon brown; narrow subterminal bar on tail, .5 inch wide; tips white; throat striations very faint greyish; flanks tinged light buff; under tail coverts warm buff; axillaries and abdomen white; bill and legs black; eyes light grey. Length, 3.8 in.; bill, .32 in.; wing, 1.9 in.; tail, 1.8 in.; tarsus, .75 in.

Type male in the National Museum Collection, Melbourne, taken at Kychering Soak, East-West Rly., S. Aust., 17/12/1908. Though only a single skin, it represents the real desert form of a widely distributed interior species. Analagous specimens are found in G.u. eremus from the same locality. The desert tone so pervades all the skins that it is not easy to tell one species from the other. I have 
seen another skin (6961) in the private collection of the late A. W. Milligan, taken at Ebano, West Australia, which answers to the above description. Wing, 2.0 inches.

Geobasileus uropygialis moora. Sub. sp. nov.

Upper surface olive brown tinged with sepia on the back; forehead feathers blackish tipped with crescents of white; crown tinged russet; upper tail coverts and base of tail tawny; broad black band on tail; tips white; under-surface white crossed by band of grey on breast; flanks tinged light buff; faintest dusky fringe on some feathers of throat; under tail coverts and axillaries white; bill and legs black; eyes white. Length, 3.8 in.; bill, .35 in.; wing, 2.1 in.; tail, 1.5 in.; tarsus, .8 in.

Type male (62) in collection of Edwin Ashby, Esq., Adelaide, taken at Watheroo, near Moora, West Australia, 6/11/1920.

This bird comes from inside the coastal belt of good rainfall, and has the upper surface and breast as dark as $G$. $u$. uropygialis but upper tail coverts and base of tail lighter (tawny), as well as under tail coverts and axillaries white like those of $G$. $u$. condora, the bill being larger than either. It represents the extreme western race separated from the type in the extreme east by the vast eremian region with its pallid form.

Geobasileus uropygialis erema. Sub. sp. nov.

Upper surface pallid drab; wings drab; forehead crescents very few; upper tail coverts and base of tail lightest cinnamon (some of the coverts tipped light buff); broad dark band on tail, tips white; under-surface white; flanks tinged light buff; bill and legs black; eyes white. Length, 3.3 in.; bill, .3 in.; wing, 1.9 in.; tail, 1.4 in.; tarsus, .7 in.

Type male (312) in the National Museum Collection, Melbourne, taken at Kychering Soak, East-West Railway, S. Aust., 17/12/1908. Co-type female (304) in the same collection from the same locality is similar, while still another specimen has a pervading cinnamon tinge especially on edges of secondaries and tail tips.

This is the extreme eremian or true desert form of the species, which I cannot find recorded as such. It has decreased in size from the pallid form, G. u. condora, become still lighter, and taken on the prevailing tone of the red ironstone desert.

Geobasileus chrysorrhous pallescens. Sub. sp. nov.

Upper surface buffy olive; forehead feathers fuscous black, each being tipped with white; frontal spot (confined to lores) and over eyes white; crown plain fuscous; wings and tail drab, tail having a broad bar of black and faint white base, upper tail coverts wax yellow, darker than in G.c. chrysorrhous; the colour running on to the outer webs of the tail; tips buffy white; throat buffy white, with slight dusky fringe to some feathers; breast pinkish buff; flanks and under tail coverts and axillaries with distinct wash of yellow; bill and legs black; eyes white. Length, 3.7 in.; bill, 0.48 in.; wing, 2.3 in.; tail, 1.5 in.; tarsus, 0.75 in.

Type male No. 36 (303) in National Museum Collection, Melbourne, was obtained by the Horn Expedition, Levi Ranges, Central Australia, in 1895.

This represents the far interior pallid race.

Geobasileus chrysorrhous westernensis. Sub. sp. nov.

Upper surface olive tinged with citrine like G. c. chrysorrhous; crown fuscous black; forehead feathers sparse!y tipped white; fron- 
tal spot and above eye white; upper tail coverts strontian yellow; base of tail light with outer webs yellow; tail mostly black with distinct white edging to inner webs near tips also on outer web; throat and abdomen white; breast chamois; flanks washed with yellow; under tail coverts and axillaries primrose yellow; eyes white; bill and legs black. Length, 3.7 in.; bill, 0.35 in.; wing, 2.2 in.; tail, 1.6 in.; tarsus, 0.7 in.

Type male (82) in the collection of Edwin Ashby, Esq., Adelaide, S.A., taken at Watheroo, near Moora, West Australia, 5/11/1920. Another specimen in the same collection has a larger bill, .4 in.

This represents the coastal and darker race in W.A. as distinct from G. c.pallidus (see Emu, vol. iii., p. 111).

Geobasileus chrysorrhous mallee. Sub. sp. nov.

Upper surface olive tinged with citrine especially on rump; crown fuscous faintly edged with grey; forehead black, a few feathers tipped white; frontal spot small and over eye white; upper tail coverts strontian yellow; base of tail light with outer webs yellow; tail mostly black with tips whitish; throat white; breast and axillaries cream buff; flanks dark olive buff; under-tail coverts cream buff; bill and legs black; eyes brown, tinged cream. Length, 4.0 in.; bill, .32 in.; wing, 2.3 in.; tail, 1.5 in.; tarsus, 7.5 in.

Type male (131) in "H. L. White Collection," Nat. Mus., Melbourne, taken at Kow Plains, N.W. Victoria, 7/9/1912. Two other specimens, both males, from the same locality are similar.

This represents a smaller and darker race found in the Mallee region, where it is not plentiful. The Mallee is of tertiary age, and in a dry belt geographically distinct from the Victorian and South Australian higher land, where its nearest congeners are found.

\section{Correspondence}

\section{To the Editors of "The Emu."}

Sirs,-In vol. xxi., page 187, in Mr. Whitlock's notes, he says, "I find no mention of the name 'Nullarbor,', etc.

Now in 1878 I was attached to a railway survey party in Northern Queensland-Townsville-Charters Towers surveyand $\mathrm{Mr}$. E. Delisser, the surveyor in charge told me that he had been out west of Port Augusta looking up country for the South Australian Government some years previously. He described the great plain, and as there was not a tree to be seen, he named it "Nullarbor," from the Latin words nulla and arbor (no tree). Mr. Delisser also told me he discovered the water at Fowler's Bay, and called the place "Eucla," as the blacks when questioned about water used to point west and say "Eucla."-Yours, etc.,

H. W. FORD.

9 Freeman Street, N. Fitzroy, Victoria, 26/1/22. 


\section{$2 \mathrm{BHL}$ Biodiversity Heritage Library}

Campbell, A. G. 1922. "New sub-species of Tit-Warblers (Acanthizae)." The Emu : official organ of the Australasian Ornithologists' Union 22(1), 63-66. https://doi.org/10.1071/mu922063.

View This Item Online: $\underline{\text { https://www.biodiversitylibrary.org/item/35198 }}$

DOI: https://doi.org/10.1071/mu922063

Permalink: https://www.biodiversitylibrary.org/partpdf/245123

\section{Holding Institution}

American Museum of Natural History Library

\section{Sponsored by}

Biodiversity Heritage Library

\section{Copyright \& Reuse}

Copyright Status: NOT_IN_COPYRIGHT

This document was created from content at the Biodiversity Heritage Library, the world's largest open access digital library for biodiversity literature and archives. Visit BHL at https://www.biodiversitylibrary.org. 